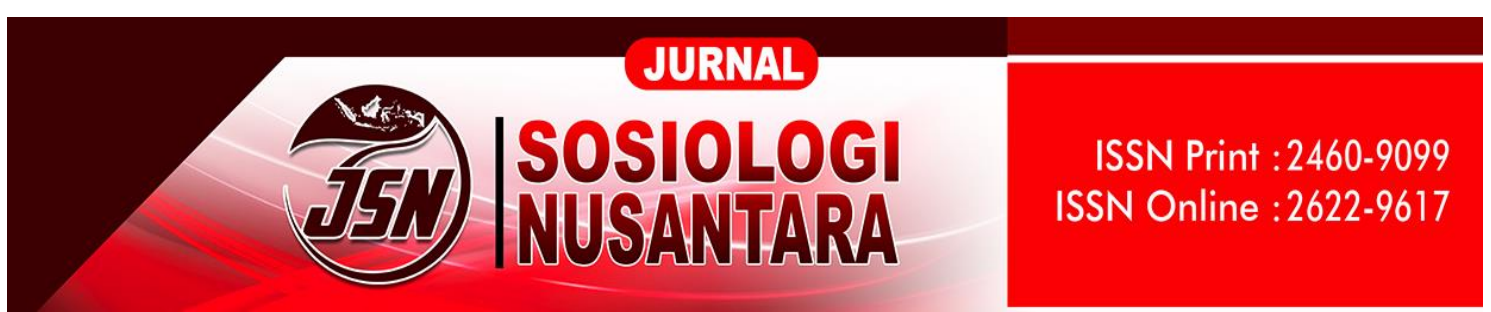

https://ejournal.unib.ac.id/index.php/jsn

DOI ://doi.org/10.33369/jsn.7.2.205-220

\title{
MISTIFIKASI "PEREMPUAN TERHORMAT" DALAM FILM SANG PENARI DARI PENGESAHAN RITUAL KE HIBURAN PANGGUNG
}

\section{MYSTIFICATION OF "RESPECTABLE WOMAN" IN THE DANCER'S FILM FROM ENDORSEMENT RITUALS TO STAGE ENTERTAINMENT}

\author{
Firdaus Mirza Nusuary' ${ }^{1}$ Fadhillah Sri Meutia ${ }^{2}$ \\ fmirza.n@unsyiah.ac.id,fadhillahsrimeutia@gmail.com
}

1. Universitas Syiah Kuala

2. Universitas Indonesia

\begin{abstract}
Abstrak
Tulisan ini berupaya mengungkapkan citra perempuan dalam film Sang Penari serta pergulatannya dengan ritual adat istiadat yang berlaku dalam masyarakat. Film Sang Penari mengusung adat Jawa serta penari ronggeng sebagai objek dalam film yang menarik untuk ditonton. Dalam film ini dikisahkan bahwa untuk menjadi penari ronggeng, seorang perempuan harus memiliki paras cantik, tubuh yang molek, pandai menyanyi serta menari untuk menghibur laki-laki. Sehingga, menjadi penari ronggeng dalam pandangan masyarakat Jawa seorang wanita yang menjadi penari ronggeng, merupakan suatu kebanggaan. Uniknya, film ini juga mengisahkan seorang istri yang sangat bangga ketika suaminya terpilih untuk bercumbu dengan sang ronggeng. Lebih jauh, tulisan ini melihat adanya ketidak beresan mengenai citra perempuan sebagai penari ronggeng sebagaimana ditampilkan dalam film Sang Penari. Melalui analisis wacana perspektif Michel Foucault Serta ditopang dengan teori dekonstruksi dari Derrida,tulisan ini berupaya melihat produksi wacana serta mitos tentang penari ronggeng dalam film Sang Penari. Terakhir, tulisan ini ditutup dengan simpulan ternyata film Sang Penari, mendekonstruksi citra penari ronggeng sebagai perempuan terhormat merupakan sebuah mistifikasi belaka untuk menjelaskan cara melanggengkan praktik pelacuran dalam masyarakat tradisional.
\end{abstract}

Kata Kunci: Perempuan, Sang Penari, ritual, analisis wacana 


\begin{abstract}
This article is aimed to reveal women's image in the 'Sang Penari' film and their fight about ritual customs which are common things in society. It elaborates image production about women's dignity on 'Sang Penari' that is directed by Ifa Isfansyah on November, $10^{\text {th }}$ 2011. This film is adapted from the novel 'Ronggeng Dukuh Paruk' novel that is written by Ahmad Tohari and published in 1982. It brings up Java's customs and Ronggeng dancers as the meaningful objects in the movie. It portrays that to be Ronggeng dancers, they must have a gorgeous appearance, a sexy body, a good voice, and a great dance to entertain men. It consequently gives a very good image and distinguishes those ladies according to Java's customs. This film also has a significant issue when a wife is proud to see her husband selected to kiss with the Ronggeng. Moreover, this study finds out that there is a crucial thing about the image of Ronggeng. By discourse analysis of Michel Foucault's perspective and supported by Derrida's theory of deconstruction, it highlights a discourse production and myth of the Ronggengs. The image of Ronggeng does not truly go to the public as a true leader in a traditional celebration. At last, this study concludes that 'Sang Penari' deconstructs the image of Ronggengs as respectable women that are merely a myth to clarify how prostitution is going capitally in local society.
\end{abstract}

Keywords: Discourse Analysis, Ritual, The Dancers, Women.

\title{
PENDAHULUAN
}

Film sebagai salah satu media yang mampu menyampaikan pesan kepada masyarakat. Salah satu film Indonesia yang banyak mendapatkan perhatian yakni film 'Sang Penari' yang dirilis pada tahun 2011, melalui piala citra film ini dinobatkan sebagai salah satu film terbaik Indonesia pada masanya. Tidak hanya sampai disitu saja lebih fenomenal lagi dikarenakan pemeran utama film ini yakni Prisia Nasution juga mendapatkan piala sebagai The Best Leading Actress, disusul Dewi Irawan yang menyabet gelar sebagai The Best Supporting Actress. Berbeda dengan film populer pada umumnya yang mengambil latar kekinian dan cenderung berlatar luar negeri sebut saja Assalamualaikum Beijing (2014) mengambil lokasi di Beijing, film Jilbab Traveler (2016) yang mengambil latar di Korea, hingga film Stupid Boss (2016) yang mengambil lokasi di Vietnam, film ini justru mengambil latar Indonesia yang memberi kesan tempo dulu tahun 1960 an dengan budaya Jawa yang sangat kental.

Beberapa penelitian serupa membahas mengenai film 'Sang Penari' diantaranya: Pudyadhita (2018) yang mengkaji film 'Sang Penari' melalui analisis semiotika dengan menganalisa objek dipadukan dengan teori John Fiske "the codes of televison". Pudyadhita melihat bahwa film ini mampu menampilkan sebuah praktik pelacuran 
namun baik penari maupun pengibing justru tidak menganggap sebagai suatu praktik pelacuran namun merupakan tradisi yang menghormati sang penari. Selanjutnya, Hendiawan (2016) mengkaji film 'Sang Penari' melalui struktur naratif, menekankan pemahaman simbol pada teks yang dibangun oleh elemen visual film. Hendiawan melalui penelitiannya menemukan bahwa narasi visual film Sang Penari wacana dan posisi subjek yang terkait dengan seksualitas, subjektivitas, kekuasaan, perbedaan kelas, dominasi dan subordinasi, hingga budaya patriarki.

Menariknya, tulisan ini justru membahas mengenai produksi citra mengenai "perempuan terhormat", dalam film Sang Penari yang disutradarai oleh Ifa Isfansyah pada 10 November 2011. Film yang diadaptasi dari novel trilogi Ronggeng Dukuh Paruk karya Ahmad Tohari diterbitkan tahun 1982. Film Sang Penari dibuat berbeda dari cerita novelnya tetapi dengan tema yang sama yakni, 'penari ronggeng' dengan latar sejarah masyarakat Jawa tepatnya di Dukuh Paruk tahun 1950-1960-an. Film ini bercerita tentang seorang penari ronggeng ${ }^{1}$, bernama Surti diperankan oleh Happy Salma yang meninggal akibat memakan tempe beracun buatan orang tua Srintil diperankan oleh Prisilia Nasution. Orangtua Srintil tidak percaya bahwa tempe buatan mereka beracun, mereka juga memakan tempe tersebut dan akhirnya meninggal. Sepeninggal orang tuanya, Srintil Pun harus hidup sebatang kara dan dibesarkan oleh kakeknya. Semenjak tragedi tersebut kepergian Surti membawa kedukaan bagi warga dukuh tidak ada lagi tarian yang diiringi dengan musik di dukuh mereka.

Srintil yang sejak kecil mengagumi sosok penari ronggeng dan bermimpi dapat menjadi penari ronggeng. Mimpi Srintil ini ditenggarai tekadnya untuk menebus tragedi akibat orang tuanya. Srintil bertumbuh besar menjadi penari ronggeng, dibantu kakeknya untuk meyakinkan Kertaraja bahwa Srintil adalah seorang penari ronggeng selanjutnya. Sejak itu, berbagai tanda ditemui oleh Kertaraja sehingga beliau percaya bahwa Srintil memang seorang penari ronggeng.

Kehadiran Srintil sebagai penari ronggeng membawa kebahagiaan kepada warga dukuh. Dalam film Srintil sebagai penari ronggeng diceritakan sebagai sosok yang memiliki keistimewaan, yakni, perempuan cantik, tubuh yang molek, pandai menyanyi serta menari untuk menghibur laki-laki. Sehingga dalam film dicitrakan menjadi penari

\footnotetext{
${ }^{1}$ Tari Ronggeng merupakan tradisi masyarakat Jawa untuk merayakan panen padi, ronggeng dipercaya masyarakat Jawa dapat memberikan kemakmuran;lihat (Pudyadhita 2018).
} 
ronggeng merupakan suatu kehormatan tersendiri. Tubuh penari ronggeng juga dipersembahkan bagi laki-laki yang mampu membayarnya dengan mahal.

Diceritakan dalam film merupakan kebanggaan seorang istri kepada suaminya apabila mendapatkan keistimewaan menikmati tubuh sang ronggeng. Tidak tanggung, pria itu diantar oleh istri ke bilik tempat bercumbu dengan sang penari, dan setelah menikmati tubuh sang ronggeng, istrinya pun menjemput pria itu, tidak lupa mengucap terimakasih kepada sang ronggeng karena melayani suaminya. Terlihat pada scene kebanggaan istri pria tersebut sambil memedih padi, terus menceritakan kepada ibu-ibu sesama pemedih sawah bahwa suaminya adalah pria yang mendapatkan kesempatan bercumbu dengan sang ronggeng. Citra penari ronggeng dalam film Sang Penari, sesungguhnya tidak menampilkan sosok ronggeng sesungguhnya yang pada hakikatnya merupakan seorang pemimpin perayaan adat dalam masyarakat tradisional. Melalui analisis wacana perspektif Michel Foucault, tulisan ini berupaya melihat produksi wacana serta mitos yang dikonstruksikan tentang penari ronggeng dalam film Sang Penari.

\section{METODE PENELITIAN}

Penelitian ini menggunakan metode penelitian deskriptif kualitatif. Penelitian ini menggunakan pendekatan analisis wacana dari Michel Foucault (1972) dengan teorinya "power and knowledge”, yang berfokus pada kekuasaan. Dalam konteks film 'Sang Penari', Foucault melihat bahwa ada kekuatan yang disebarkan melalui produksi makna melalui teks film menghasilkan wacana sebagai suatu praktik sosial. Pertama, penelitian ini menganalisis film 'Sang Penari', dengan pendekatan Foucault melalui pemaknaan bahasa yang digunakan oleh tokoh-tokoh yang berperan dalam film yang menggunakan bahasa Jawa. Kekuasaan merupakan wacana, pengetahuan, tubuh dan subjektivitas: Apa yang membuat kekuatan bertahan, apa yang membuatnya diterima, hanyalah fakta bahwa hal itu tidak hanya menimbang kita sebagai kekuatan yang mengatakan tidak, tapi hal itu melintasi dan menghasilkan sesuatu, hal itu menginduksi kesenangan, membentuk pengetahuan, menghasilkan wacana. Ini perlu dianggap sebagai jaringan produktif yang berjalan melalui keseluruhan badan sosial, lebih daripada sekadar contoh negatif yang fungsinya adalah represi (Foucault 1980: 119). 
Selanjutnya Kedua, melalui pakaian adat Jawa yang digunakan para tokoh dalam film ini. Analisis wacana digunakan untuk menjelaskan dunia sosial, termasuk subjek dan objeknya, yang diwacanakan (Foucault 1972). Fokusnya harus pada bagaimana efek kebenaran diciptakan dalam wacana. Apa yang akan dianalisis adalah proses diskursif yang melaluinya wacana dibangun dengan cara yang memberi kesan bahwa mereka mewakili gambaran realitas yang benar atau salah(Jorgensen and Phillips 2010).

Ketiga, pada tahapan dekonstruksi penelitian ini menggunakan pendekatan Derrida (1992) mendekonstruksikan wacana Sang Ronggeng sebagai sebuah kehormatan, lebih lanjut pada tahapan ini kedudukan perempuan sebagai ronggeng dalam masyarakat dibongkar melalui pendekatan dekonstruksi untuk melihat gejalagejala sosial yang dapat diakibatkan oleh film 'Sang Penari' dalam masyarakat. Kemudian, pandangan Gramsci (1972) mengenai hegemoni yang terjadi dalam masyarakat serta implikasi sosial mengenai wacana serta citra penari ronggeng dalam masyarakat.

\section{PEMBAHASAN}

\section{Produksi wacana "Penari Ronggeng" dalam Film Sang Penari}

Tokoh Srintil yang dikisahkan sebagai seorang warga dukuh Paruk yang bercita-cita menjadi penari ronggeng. Namun, dikisahkan bahwa untuk menjadi seorang penari ronggeng tidaklah hanya berbekal cantik dan pandai menari, tetapi ada beberapa syarat yang harus dilakukan sebagai sebuah tradisi salah satunya yaitu tradisi Bukak klambu ${ }^{2}$. Pada scene berikut:

\section{Gambar 1}

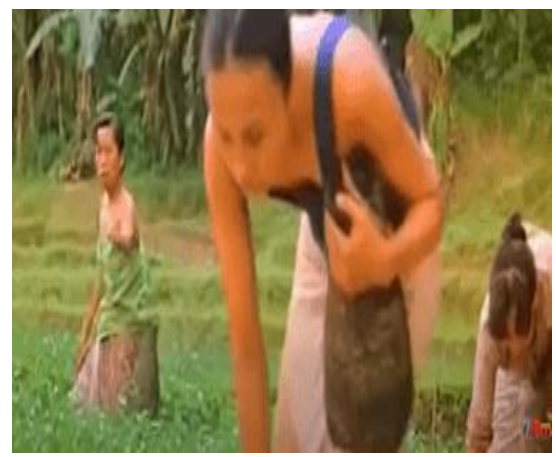

Sumber : Dokumentasi Peneliti, 2021

\footnotetext{
2 Berarti bahwa keperawanan Sang Penari ronggeng ditawarkan untuk laki-laki dan yang mampu membayar paling mahal yang mendapatkannya.
} 
Teks: Warga 1: "wah.. seneng tenan ya yuk, dukuh Paruk wes arep ndueh ronggeng maning". (wah senangnya ya, Dukuh Paruk sebentar lagi punya ronggeng)

Warga 2: “iya ya.. nanti kalau benar Srintil sudah jadi ronggeng, pasti bojoku yang akan dapat perawannya"

Warga 3: "Aja asal ngomong rika yuk, ronggeng ke milih seng akeh duite mesti bojoku sing menang!”

Warga 2 : "Eeh bojoku itu duitnya banyak kalau semua kambingnya dijual, Sing penting bisa merawani Srintil!"

Pada scene di atas film 'Sang Penari' ditenggarai menampilkan mengaburan makna tentang sosok penari ronggeng yang semula diriwayatkan sebagai kehadiran Dewi Sri yang membawa kemakmuran bagi sawah masyarakat dukuh. Oleh karena itu, melalui analisis wacana tulisan ini akan memaparkan bagaimana praktik makna dimainkan di dalam film 'Sang Penari', hingga cara film memproduksi wacana kepada khalayak penonton. Dari teks diatas, ditampilkan bahwa menjadi ronggeng pada hakikatnya tidak sekedar menjadi 'penari', namun sebagai ronggeng yang menjadi idola warga diwajibkan untuk mau melakukan berbagai macam aktivitas, seperti seksual diantaranya mau berhubungan badan dengan pria yang membayarnya paling mahal.

Film Indonesia sebagai media ekspresi sutradara untuk menyampaikan pesan kepada masyarakat sebagai penonton. wacana media dan budaya melalui berita serta hiburan seperti televisi dan film-film. Makna dalam film muncul dari interaksi berbagai gambar, suara, musik, isyarat, efek kamera, dll. Kesemuanya itu merupakan perangkat kronologis dalam penyuntingan film, mempengaruhi hasil teks narasi dalam memberikan pemahaman dan interpretasi membutuhkan partisipasi aktif penonton.

Film Sang Penari, yang bercerita tentang seni tradisional masyarakat Jawa yakni, 'penari ronggeng'. Film ini pada awalnya menampilkan citra penari 'penari ronggeng' sebagai 'perempuan terhormat'. 
Gambar 2

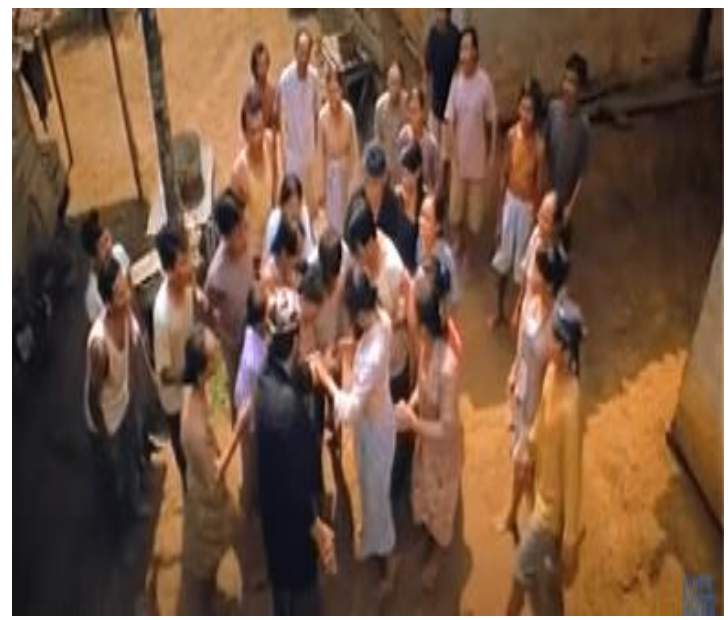

Sumber : Dokumentasi Peneliti, 2021

Teks: Sakarya: Sedulur-sedulurku kabeh Srintil dipilih menjadi ronggeng disambut dengan sorak sorai warga dukuh

Gambar 3
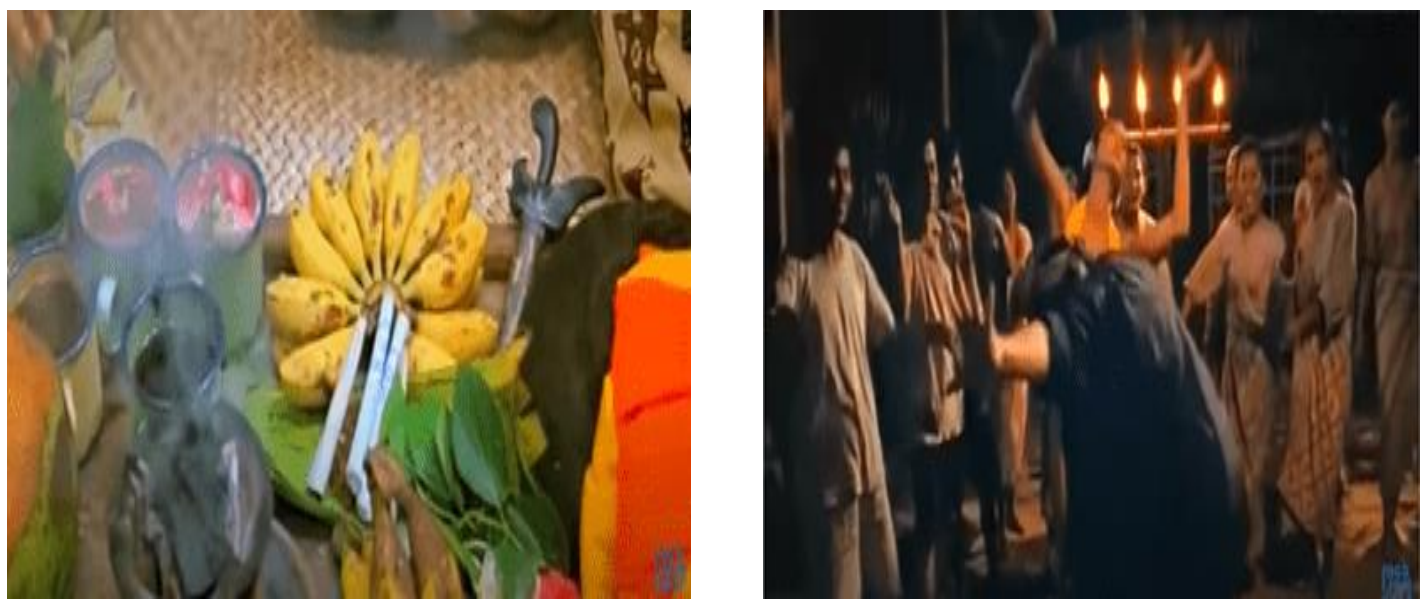

Sumber : Dokumentasi Peneliti, 2021

Teks: Sakarya: Ini cucuku Srintil (dengan bangga)

Melalui pandangan sosiologi untuk mengkaji film dan khalayak penonton. Terdapat dua hal yang penting untuk diperhatikan yakni; pertama, mempertanyakan apakah kekerasan film yang menjadi indikator kekerasan pada masyarakat. Kedua, kembali menanyakan apakah film mempromosikan nilai-nilai sosial, dan dalam beberapa dekade terakhir bagaimana masyarakat menafsirkan film (lihat, Patton,2007). Oleh karena itu, film yang memproduksi teks, maksud teks disini sebagai multi-fungsi 
dalam pengertian ini, di mana wacana digambarkan sebagai bagian dari praktik sosial cara bertindak, cara untuk mewakili, cara menjadi atau untuk melihat hubungan teks terhadap dunia dan sosial yang lebih luas, dan kepada orang-orang yang terlibat.

Hal tersebut menjadi sebuah kebanggaan bagi warga dukuh, dimana para istri berebutan agar suaminya dapat berhubungan dengan sang ronggeng dengan harapan yang diyakini oleh warga dukuh bahwa setelah suaminya berhubungan badan dengan sang ronggeng, sang suami akan dengan mudah membuahi istrinya. Tugas ini tentunya harus dilakukan oleh Srintil yang kini menjadi ronggeng.

Melalui pendekatan wacana yang menggambarkan praktik diskursif yang dibentuk oleh hubungan kekuatan terhadap konstruksi identitas sosial, hubungan sosial dan sistem pengetahuan dan kepercayaan. Pendekatan teks sebagai tindakan, representasi, identifikasi bahasa sebagai teks yang multi fungsi, bahwa teks secara bersamaan memiliki fungsi 'ideasional', 'interpersonal 'dan 'tekstual'. Artinya, teks secara simultan mewakili aspek dunia (dunia fisik, dunia sosial, dunia mental); memberlakukan hubungan sosial antara peserta dalam acara sosial dan sikap, keinginan dan nilai peserta; dan secara koheren dan kohesif menghubungkan bagian-bagian teks bersama-sama, dan menghubungkan teks dengan konteks situasional mereka (Halliday 1978, 1994). Sebagai penobatan Srintil sebagai Ronggeng Dukuh, tubuhnya kini menjadi milik publik. Rasus yang mencintai Srintil tentunya merasa tidak suka akan tugas yang harus dilakukan Srintil sebagai sang Ronggeng. Dengan perasaan tidak karuan Rasus meninggalkan dukuh dan memilih bekerja serabutan disana. Akhir cerita, Rasus menjadi tentara melalui pertemuannya yang tidak diduga dengan Sersan Binsar. Dari sini, kita dapat melihat bagaimana 'tubuh' Srintil sebagai praktik sosial yang dikemas ke dalam citra 'Sang Penari'.

\section{Dekonstruksi tokoh Srintil dalam Film Sang Penari}

Penelitian ini menggunakan teori dekonstruksi Derrida yang berpijak pada tiga asumsi. Pertama, bahasa merupakan suatu hal yang tidak pernah stabil dan memiliki makna yang berlimpah ruah. Oleh karena itu bagi Derrida bahasa tidaklah statis melainkan melalui proses secara terus menerus, bahasa itu bukanlah suatu 'struktur' tetapi 'menstruktur'. Penolakan ini dilakukan Derrida dengan menunjukkan bahwa bahasa disusun secara terus menerus. Bagi Derrida, penanda hanya menunjuk kepada 
penanda yang lainnya. Oleh karena itu, apabila suatu penanda tanpa logos (pertanda, makna) yang kuat, kemungkinan ke arah permainan sangat dimungkinkan. Kedua, instabilitas yang demikian sehingga interpretasi tekstual menghasilkan pembacaan yang beraneka ragam. Sehingga teks dapat dapat merekonstruksi logika yang dibangunnya sendiri. Ketiga, konsekuensi atas tidak adanya klaim istimewa pembacaan makna makna interpretasi tekstual menjadi sebuah interpretasi pemaknaan tanpa batas (lihat Derrida,1992).

Dekonstruksi (dalam Derrida,1992) dalam membaca teks dipetakan menjadi tiga bagian yakni: a) oposisi biner, dalam teks oposisi biner dimaksudkan sebagai suatu keistimewaan pada satu unsur dan unsur lainnya termarginalkan. Derrida menggugat ini dalam bahasa seperti pada 'tulisan' dan ‘tuturan' yang dianggap lebih istimewa karena merupakan representasi dari tulisan.

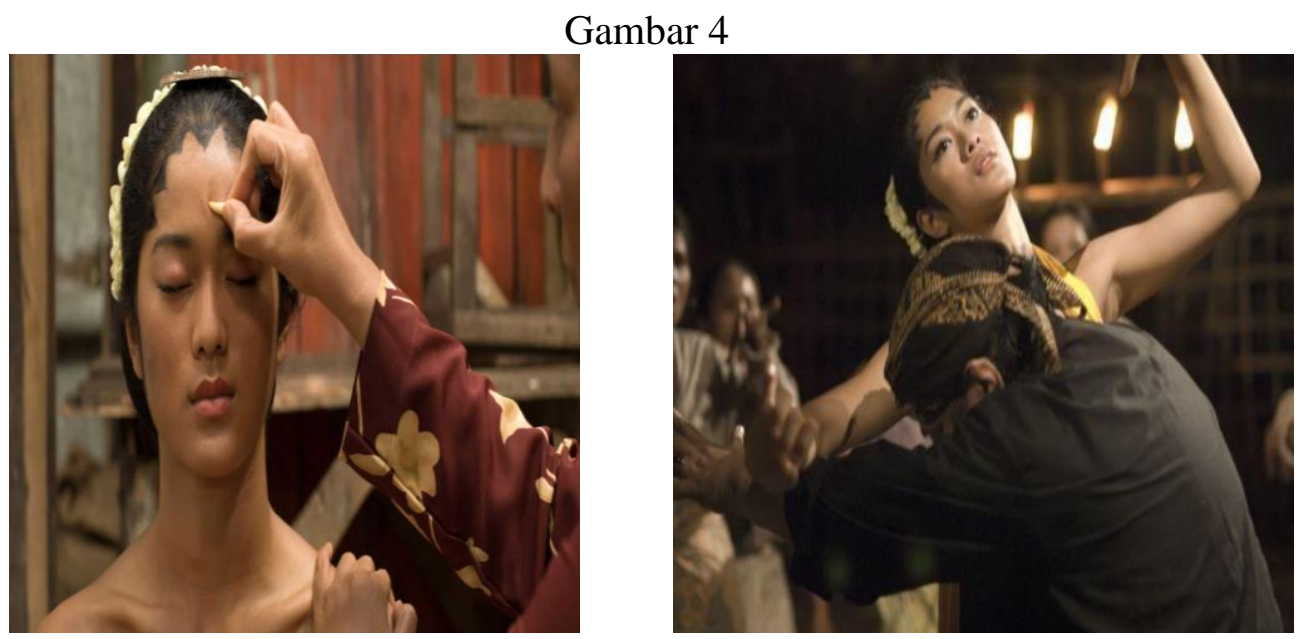

Sumber : Dokumentasi Peneliti, 2021

Scene diatas merupakan bagian yang menggambarkan ritual ronggeng, tokoh Srintil yang dibacakan mantra dan memulai melakukan ritual menari bersama para pengibing. Semua warga Dukuh Paruk bersorak menari bersama ronggeng, film ini menggambarkan betapa warga Dukuh Paruk memuja kehadiran ronggeng. Namun, dalam pandangan Foucault (2010) ada pesan yang terkandung dibalik teks sebuah pesan yang dalam pandangan Derrida (1992) merupakan sesuatu yang direkonstruksi yakni praktik pelacuran yang dimulai saat sang ronggeng mulai menari hingga berlangsungnya ritual bukak kelambu.

b) blind spot, dimaksudkan sebagai wilayah terselubung dalam suatu teks. Ini dikarenakan hubungan antara teks dan pengarang bersifat tidak langsung tetapi dimediasi melalui bahasa. Oleh karena itu hubungannya tidak dapat dikuasai secara 
penuh. Hal ini juga dapat berarti bahwa bagian terselubung sebagai bagian ketidaksadaran dari teks, sehingga pengarang dapat dikritisi.

\section{Gambar 5}

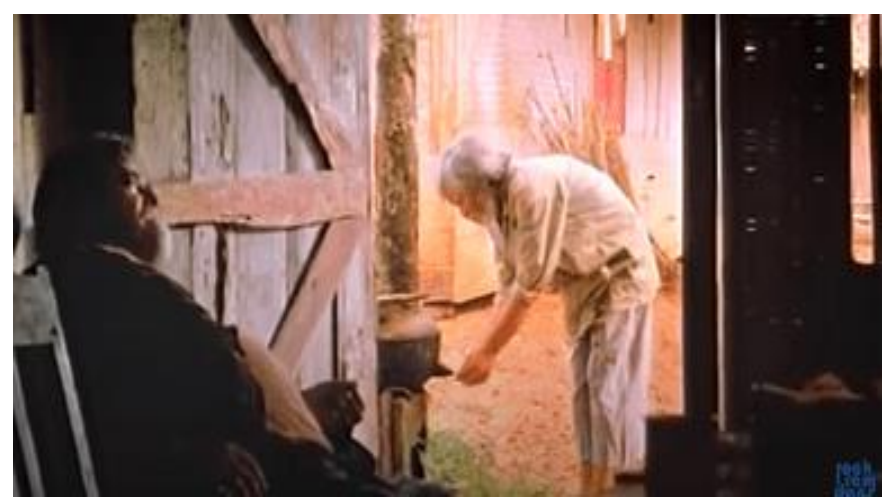

Sumber: Dokumentasi Peneliti, 2021

Teks:

Kartareja : "terus kapan kita mau mulai buka kelambu kang?"

Sakarya : "Manut hitungan ya ngesuh, malem jumat"

Kartareja : "Iya saiki kliwon"

Sakarya : "Terus sampean masih minta ringgit emas?"

Kartareja : "Yahh itu harga yang pantes boleh apa saja... asal nilainya sama"

Sakarya : "Tapi kalau kemahalan apa enggak nyalahin aturan itu kang?”

Kartareja : "Kemahalan? Hehehehe apa ada ronggeng yang manisnya seperti cucu sampean?”

Melalui teks di atas, tubuh Srintil sebagai Penari Ronggeng dihargai dengan ringgit, ini sebagai upah atas ritual lelang 'buka kelambu'. Makna melibatkan referensi ke masa lalu (pengalaman yang sudah berlalu), tindakan melibatkan referensi ke masa depan serta masa lalu. Tindakan dimungkinkan karena kesadaran memproyeksikan tujuan atau akhir tindakan di masa depan, sehingga tindakan yang telah selesai diproyeksikan dalam khayal oleh kesadaran yang memberi makna pada tindakan secara keseluruhan. 


\section{Gambar 6}
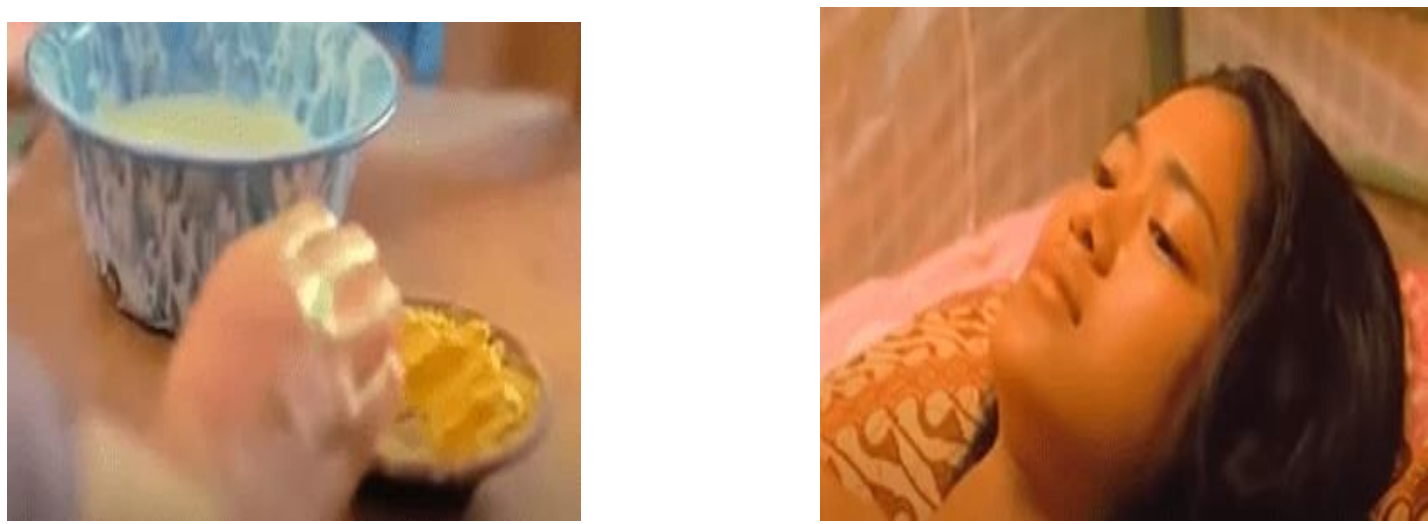

Sumber : Dokumentasi Peneliti, 2021

Pada scene ini menampilkan Nyai Kerteraja yang sedang melakukan ritus kewanitaan kepada Srintil untuk persiapan ritual bukak kelambu dan menasehatinya menyoal tahapan menjadi ronggeng.

Nyai Kartareja : "Ronggeng kui ora mung perkara urusan sindur, ning juga urusan kasur, urusan batur, urusan sumur"

Nyai Kartareja : "Tenang baelah cah ayu, ronggeng kui pancen kudu bisa ngatur wong lanang sudah gak apa- apa tenang bae"

Nyai Kartareja : "Kamu kudune ngerti, kamu akan berhenti jadi ronggeng kalo kamu hamil, aja kuatirlah inyong wes ngerti gimana caranya jadi ronggeng lebih lama"

Ikon penari ronggeng merupakan bagian dari kebudayaan lokal, namun film menampilkan realitas bahwa sang penari ronggeng tidak hanya digambarkan sebagai perempuan yang pandai menari tetapi juga mengharuskan untuk melayani pria dengan pelelangan tubuhnya. Tentunya, ini jauh dari hakikat seorang penari ronggeng yang merupakan pemimpin upacara adat. Film Sang Penari, justru menampilkan penari ronggeng dengan citra yang berbeda pada hakikatnya. Melalui ikon Sang Penari yang merupakan produk kebudayaan, menyiratkan praktik kekuasaan dalam masyarakat pada masa itu kepada khalayak penonton. Menjadi catatan, bahwa baik penonton dan pembuat film disini pada hakikatnya tidak pernah mengalami hidup pada tersebut. Sehingga, citra Sang Penari Ronggeng yang ditampilkan oleh film dapat mempengaruhi persepsi masyarakat mengenai ronggeng. Dikarenakan teks-teks serta representasi ronggeng yang ditampilkan sebagai perempuan yang menjual tubuhnya melalui ritual 
adat. Film memiliki kekuatan untuk menjangkau khalayak dari semua segmentasi, sehingga film itu sendiri memiliki kuasa untuk mempengaruhi khalayak. Sebaliknya, Turner (Sobur 2012) berargumen bahwa film merepresentasikan realitas, film mampu representasi realitas melalui tanda-tanda dan ideologi yang diselipkan ke dalam film. Dalam film sang penari melalui industri perfilman terjadi relasi kuasa oleh pembuat film untuk menyajikan tontonan yang diperuntukkan untuk khalayak penonton, praktik kekerasan terhadap perempuan dihadirkan melalui berbagai ekspresi serta struktur masyarakat yang ditampilkan dalam masyarakat.

c) Kontradiksi internal teks, suatu teks apabila selesai ditulis bukanlah suatu teks yang dalam konstruksinya telah selesai seperti pandangan Saussure yang melihat teks sebagai sesuatu yang stabil. Derrida (lihat Derrida, 1972)(Derrida 1972), justru melihat dalam teks terdapat suatu kebenaran yang menjadi tugas pembaca untuk menemukannya. Ikon Srintil sebagai perempuan yang sebenarnya mengalami kekerasan yang berasal dari sistem sosial. Dalam film ikon Srintil sebagai Sang penari mengorbankan cintanya dengan Rasus demi cita-citanya menjadi ronggeng dukuh Paruk. Dalam hal ini ikon Srintil sebagai perempuan sebenarnya mengalami kekerasan, jika dilihat dari perspektif relasi gender terdapat suatu ketimpangan. Praktik ini dilanggengkan oleh sistem sosial masyarakat hingga institusi perfilman.Melalui serangkaian praktik budaya sehari-hari yang tampaknya biasa-biasa saja. Ini memeluk prinsip-prinsip kunci pendekatan Marxis budaya Gramsci (1971)(Gramsci 1971), secara kritis merupakan konsep hegemoni. Gramsci menciptakan istilah hegemoni sebagai alat untuk mengekspresikan sistem ide dan kepercayaan yang dominan dimana kelas penguasa dapat memberikan kekuasaan atas masyarakat. Menurut Gramsci, urutan hegemonik rentan terhadap tantangan dari bawah. Dengan memanfaatkan posisi ini sebagai sarana untuk menginvestigasi ulang kehidupan budaya.

Film ini menampilkan wacana tentang hubungan ronggeng dan seksualitas wanita yang dikemas melalui medium film. Proses pembuatan film dan permainan kamera, ruang kontrol diam-diam melakukan pengembaraan kepada audiens ke dalam posisi dari mana mereka dapat "melintasi" ke sisi lain dan melihat perspektif yang bukan miliknya(Khorana 2013).

Sebagai wacana yang berlangsung dinamis, mengubah sumber daya dalam ruang dan waktu yang terus menerus menghasilkan makna yang penting untuk dianalisis lebih 
lanjut, mengenai perkembangannya secara berurutan. Analisis ini merupakan analisis yang dinamis serta progresif untuk menemukan hubungan antara perangkat film dalam membangun struktur wacana yang berlangsung sebagai teks dengan kesimpulan berdasarkan penalaran. Interpretasi film adalah proses pembuatan makna relasional dan dalam menyimpulkan secara aktif mengenai proporsional dari konten, asumsi dan hipotesa yang membuat audiens mengikuti dan menerima isyarat dalam teks (lihat Wildfeur,2014).

Seksualitas perempuan melalui ikon Srintil sebagai ronggeng pada satu titik mengkonstruksi wacana penari 'ronggeng'sebagai perempuan yang menjual tubuhnya kepada kaum pria sebagai sesuatu yang sudah menjadi tradisi. Hubungan sosial tidak langsung tidak dapat mengandalkan proses normal pemahaman intersubjektif melalui ucapan, gerak tubuh, perilaku yang diamati, dll. Sebaliknya, aktor memahami satu sama lain melalui tipe ideal. Pemahaman mengenai orang-orang sezaman (orang-orang yang hidup dalam masyarakat yang sama tetapi tidak kenal) dalam kerangka skema tipifikasi yang mengimpersonalisasi dan menganonimkan mereka dalam hal fungsi atau peran mereka. Tahun terakhir abad 20, tepatnya pada tahun 2000 adalah tahun yang membawa dunia global kearah yang lebih modern. Akhir dari Orde Baru di tahun 1998 juga mengakhiri Departemen Informasi, yang telah menguasai industri film. Dunia hiburan juga mengalami banyak perubahan, dalam hal ini, khususnya industri perfilman(Sen 1994). Film di Indonesia telah mengalami banyak perubahan, baik dari segi teknologi, cerita, serta setting. Melalui film Sang Penari, ronggeng dicitrakan sebagai suatu praktik yang walaupun diterima oleh masyarakat dukuh Paruk namun sebenarnya menyiratkan pelacuran terselubung. Wacana ini disampaikan kepada audiens melalui proses menonton yang diselipkan kedalam film.

\section{KESIMPULAN}

Film 'Sang Penari' (2011) menceritakan mengenai kehidupan seorang penari ronggeng yang ada di Dukuh Paruk bernama Srintil. Meskipun film ini sudah tayang 10 tahun yang lalu (terhitung hingga tahun 2020), namun film Sang Penari masih cocok untuk ditonton saat ini. Fokus cerita yang berkisah mengenai kisah cinta Rasus dan Srintil dengan dibumbui berbagai cerita lainnya seperti kehidupan seorang penari ronggeng dan keadaan Indonesia pada tahun 1960-an membuat film ini semakin 
menarik untuk ditonton. Tampilan film yang kental dengan budaya lokal lengkap dengan tradisi masyarakat Jawa dengan menghadirkan ronggeng beserta lika-liku kehidupan tokoh Srintil sebagai 'Sang Penari' dikemas kedalam film yang disuguhkan kepada khalayak penonton. Pandangan Foucault dalam Power and Knowledge (1980) dalam konteks film 'Sang Penari' wacana diproduksi melalui teks. Pertama, melalui bahasa tokoh dalam film 'Sang Penari' menggunakan bahasa Jawa untuk berkomunikasi sehingga dapat dirasakan sisi budaya tradisional yang diangkat dalam film. Kedua, pakaian yang digunakan pemain dalam film ini terutama tokoh utama 'srintil' sebagai tokoh utama yang menggunakan kemben dan sampur yang merupakan pakaian adat Jawa sehingga dapat dipahami bahwa tarian yang dilakukan merupakan tarian Jawa.

Selanjutnya yang ketiga, pada tataran dekonstruksi Derrida (1992) menjelaskan dalam film ini tentang kepercayaan masyarakat Dukuh Paruk bahwa menjadi penari ronggeng merupakan suatu kehormatan bagi seorang wanita, kepercayaan ini justru dibongkar dan didekonstruksi sendiri melalui teks film salah satunya dengan menampilkan ritual Bukak kelambu yang harus dijalani seorang ronggeng dalam penobatannya. Dalam hal ini ritual Bukak Kelambu, dikonstruksikan oleh film 'Sang Penari' merupakan sebuah kehormatan bahkan kebanggaan dinilai dengan materi yang mahal. Namun sesungguhnya jika ditelisik lebih dalam ritual ini memperdagangkan kehormatan sang ronggeng sebagai wanita. Praktik ini kemudian menurut pandangan Gramsci (1972) sebuah gejala sosial yang mampu menghegomeni masyarakat melalui implikasi sosial. Dimana, implikasi sosial dikonstruksikan oleh film ini melalui tokoh Srintil yang merupakan seorang perempuan yang sudah menyukai tari sejak kecil. Hingga akhirnya saat dewasa, ia berhasil menjadi satu-satunya penari ronggeng yang dimiliki oleh Dukuh Paruk, setelah penari ronggeng yang sebelumnya meninggal dunia.

Film Sang Penari merepresentasikan perempuan Jawa di tahun 1950-60an, menampilkan ikon Srintil diceritakan sebagai Ronggeng dukuh Paruk kala itu. Produk industri media dan budaya dapat dibuat dengan makna yang diinginkan, bahwa gambar, teks dan produk semacam itu dianggap tidak dapat dikendalikan. Dalam hal ini, makna baru dan subversif dapat dikaitkan dengan sumber media dan budaya yang memberikan tantangan baru pada tatanan hegemonik.

Menjadi seorang penari Ronggeng merupakan cita-cita Srintil sejak kecil, juga harapan masyarakat akan kehadiran ronggeng di dukuh Paruk yang dipercayai 
membawa kemakmuran pada pertanian rakyat. Film Sang Penari mengkonstruksi citra penari Ronggeng, yang dilegendakan sebagai pemimpin upacara adat dan dikisahkan sebagai jelmaan legenda Dewi Sri sebagai dewi padi yang dapat memberikan kemakmuran kepada petani sawah. Namun, dalam film Sang Penari justru penari ronggeng Dukuh Paruk dicitrakan sebagai perempuan yang berprofesi sebagai penari yang tubuhnya dilelang untuk kaum pria sebagai tradisi upacara pengangkatannya sebagai Sang Ronggeng. Tulisan ini melihat bahwa film Sang Penari, memberikan pandangan kepada khalayak penonton mengenai penari ronggeng, sebagai sebuah praktik prostitusi terselubung yang disahkan oleh institusi sosial dan dikemas oleh industri perfilman. Penelitian ini memberikan pandangan kepada khalayak mengenai diskursus kebudayaan melalui film yang mampu mengkonstruksi pandangan penonton mengenai citra yang dilekatkan kepada penari ronggeng tidak hanya penari ronggeng di dukuh Paruk, Banyumas tetapi juga berdampak pada penari ronggeng di Indonesia secara lebih umum.

\section{DAFTAR PUSTAKA}

Derrida, J. 1972, Dissémination, Paris, Seuil.

Derrida, J. 1992, 'Force of Law: The "Mystical Foundation of Authority", in D.Cornell, M.Rosenfeld and D.G.Carlson (eds), Deconstruction and the Possibility of Justice, London and New York, Routledge.

Foucault, M. 1972. The Archeology of Knowledge. London: Routledge.

Foucault, M. 1980. 'Truth and power', in C. Gordon (ed.) Power/Knowledge. Selected Fairclough, 2010., Critical Discourse Analysis The Critical Study of Language. London and New York: Routledge

Gramsci, A. 1971. Selections from the Prison Notebooks, Lawrence and Wishart, London.

Hendiawan, Teddy 2016. Wacana Seksualitas Poskolonial pada Teks Naratif Film Sang Penari. Journal Pantun :Institut Seni Budaya Indonesia.

Janina, wildflower. 2014. Film Discourse Interpretation: Towards a New Paradigm for Multimodal Film Analysis. New York: Routledge. 
Jorgensen Marianne dan Philips Louise, Analisis wacana Teori dan Metode,2010:Yogyakarta:Pustaka Pelajar.

Patton, Cindy. 2007. Cinematic Identity: Anatomy of a Problem Film. New York: University of Minnesota Press.

Sen, Krishna.1994.Indonesian Cinema: Framing the New Order.London and Jersey: Zed Books Ltd.

Sobur,2012, Analisis Teks Media, Bandung : Remaja Rosdakarya

Sukhmani, Khorana.2013. Crossover Cinema: Cross-Cultural Film from Production to Reception. New York: Routledge.

Derrida, Jacques. 1972. Dissemination. Paris: Seuil.

Foucault, Michel. 1972. The Archeology of Knowledge. London: Routledge.

Gramsci, Antonio. 1971. Selections from the Prison Notebooks. London: Lawrence and Wishart.

Jorgensen, Marianne w., and Louise J. Philips. 2010. Analisis Wacana: Teori \& Metode. Yogyakarta: Pustaka Pelajar.

Khorana, Sukhmani. 2013. Crossover Cinema: Cross-Cultural Film from Production to Reception. New York: Routledge.

Patton, Cindy. 2007. Cinematic Identity: Anatomy of a Problem Film. New York: University of Minnesota Press.

Pudyadhita, Tiara. 2018. "Representasi Perempuan Penari Dalam Kesenian Rakyat Ronggeng (Studi Semiotika Pada Film Sang Penari).” Interaksi Online 1 (1).

Sen, Krishna. 1994. Indonesian Cinema: Framing the New Order. New Jersey: Zed Books Ltd.

Sobur, Alex. 2012. Analisis Teks Media: Suatu Pengantar Untuk Analisis Wacana, Analisis Semiotik, Dan Analisis Framing. Bandung: PT Remaja Rosdakarya.

Wildfeuer, Janina. 2014. Film Discourse Interpretation: Towards a New Paradigm for Multimodal Film Analysis. New York: Routledge. 